\title{
EXPANDing THE SUITE OF MEASURES OF GENDER-BASED DisCRIMINATION: GENDER DifFERENCES IN ABLUTION FACILITIES IN SOUTH AFrica
}

\author{
Renier Steyn \\ Graduate School of Business Leadership, University of South Africa
}

Accepted: April 2012

\begin{abstract}
International treaties, national legislation and local by-laws all advocate the equal treatment of men and women, but claims of gender-based discrimination continue. Indicators of discrimination against women, including employment ratios and differences in income, show that there have been considerable gains in the recent past. These measures are, however, often biased. In this study a different, specific and concrete method of describing and detecting discrimination is presented, namely the difference in the number of ablution facilities provided for each gender group in public spaces. Ablution facilities at airports, train stations and shopping centres in four major South African cities $(\mathrm{N}=128)$ were inspected. Medium to large differences in the respective number of facilities were found (eta ${ }^{2} .05$ to .13 ), with women receiving fewer service facilities than men. These results suggest that, despite progressive legislation and vigorous affirmative action in South Africa, local women are still being discriminated against on a very concrete, visible level. The effectiveness of the measurement tool is also discussed.
\end{abstract}

Key words: public access, gender discrimination

JEL: R53, J16, 71

1

\section{Introduction}

Both the 1996 Constitution of the Republic of South Africa and the United Nations Universal Declaration of Human Rights (United Nations, 1948) promote the principle that all people are equal and that all individuals should have equal access to the resources of their countries. In South Africa, the Basic Conditions of Employment Act of 1997 and the Employment Equity Act of 1998 specifically refer to issues of gender equality. The Employment Equity Act in particular refers to the affirmation of women's rights in light of previous discrimination (South Africa, 1998). This suggests that women were treated differently and reductively in the past and that this situation may in fact be continuing today.

Several methods can be used to assess the extent to which discrimination against women occurs. The most frequently-used used method, particularly in capitalist societies, is to assess the proportion of women active in the labour market and the organisational level at which they are employed. Quite often the per capita income generated by women is used as an indicator of gender-based discrimination. This method is, however, skewed as a measure of equality because some women may prefer to be, at least temporarily, unemployed or employed on a more flexible basis, for example by occupying part-time positions. This affects their employment numbers and the average income they earn (Cascio, 2010; Leopold \& Harris, 2009).

Another method used to detect genderbased discrimination is by means of self-report surveys (eg Bible \& Hill, 2007; Carr, Ash, Friedman, Szalacha, Barnett \& Palepu, 2000). In these surveys, participants are typically asked to assess the level of discrimination they experience, thereby capturing perceived bias. However, surveys are, by their very nature, often flawed (Shaughnessy, Zechmeister \& Zechmeister, 2009), particularly surveys that assess aspects of out-groups (cf Iyer \& Ryan, 2009; Navarrete, McDonald, Molina \& Sidanius, 
2010). For example, when asked about discrimination against women, men often report (and possibly perceive) less of such discrimination than what women themselves would actually report (Sipe, Johnson \& Fisher, 2009). Surveys are therefore not always an objective or unbiased measure of discrimination.

In this paper the (unequal) distribution of public toilet facilities will be used as a(n) (additional) measure of gender-based discrimination. Unequal ratios are reported for the distribution of public toilets in Western Europe (Gershenson \& Penner, 2009), in the United Kingdom (Greed, 2009) and the United States of America (Anthony \& Dufresne, 2009), as well as in most of the Third World (Moore, 2009). The inequality is interpreted by the listed authors as being indicative of detrimental discrimination against women. However, the full extent of discrimination is unknown, because, while the articles report unequal ratios, they present no numerical values. Furthermore, no specific statistics for South Africa could be located.

The unequal distribution of toilets implies discrimination and problems at at least three different levels. The first is a political case, as suggested in the first paragraph and one which is guided by legislation. Legislation gives women the right to equal access. "At particular historic[al] moments and in different locations, the absence of toilet facilities has signalled to various subordinate social groups that they are outsiders to the body politic and that there is no room for them in public space" (Gershenson \& Penner, 2009:ix-x).

Secondly, discrimination in the allocation of toilets suggests a psychological schematic problem, as the spaces people inhabit inform them how to see themselves, and how others the designers (and by proxy lawmakers, politicians and society) - see them. These facilities can be thought of as "mirrors with which we can examine the way we want to see both ourselves and others" (Schweder, 2009:182). Schweder also states the following: "Buildings give materiality to the behavior that we consider orderly and, ultimately, enforce this order" (Schweder, 2009:182).

Thirdly, discrimination in the allocation of ablution facilities constitutes a health risk. Anecdotal evidence suggests that long queues often form at facilities designated for women, while this is seldom a problem at the facilities designed for men. This suggests that women spend more time and endure discomfort in accessing toilet facilities. This may also result in health complaints, such as incontinence, distended bladders and urinary infections (Greed, 2009; Gershenson \& Penner, 2009). Furthermore, it should be borne mind that women are often accompanied to public toilet facilities by babies or small children and that they therefore have different needs when it comes to the number of facilities, safety and hygiene. Women therefore often need to spend more time than men do in these spaces.

But with what would an equal distribution of toilets equate? Anthony and Dufresne (2009) suggest three measures: equal square footage, an equal number of toilets, or equal waiting time. When equal square footage is allocated to restrooms for males and females, the possibility exists of producing an unequal number of toilet facilities, as toilets (the dominant features in female restrooms) generally take up more space than urinals (found only in men's restrooms). Providing an equal number of toilets per group, and suggesting that this results in a bias-free solution is also logically flawed. In this respect, Gershenson and Penner (2009) argue that, owing to women's toilet needs and uses, distributing toilets equally between men's and women's restrooms actually produces an unequal result. It is suggested that an equal waiting time would most likely be the more just measure of distribution.

It will be argued in this paper that at least equal numbers of facilities should be allocated to women and that, if this were not carried out, it could constitute gender-based discrimination. Therefore, if discrimination were to be found when this measure was applied (amounting to underestimation of discrimination) it would provide clear evidence of the practice. Applying the number of toilets as a detector of discrimination produces unbiased, physical and tangible information that reflects the level of gender-based discrimination. It is not suggested that this information would provide a comprehensive measure of discrimination. It should rather be seen as an additional or complementary indicator. 
2

Purpose and objectives of the research

The purpose of this article is to introduce an alternative measure of gender bias, a measure based on tangible evidence, to be used in conjunction with other measures in order to provide a comprehensive picture of the extent of the progress relating to the elimination of gender-based discrimination. The author will then present the results of the survey of ablution facilities in South Africa and report on the levels of discrimination in South Africa assessed by means of this supplementary measure.

3

\section{Literature review}

The literature will be presented under three headings. First, different measures of gender equity will be discussed. Under the second heading attention will be given to some requirements of an effective measure and under the third heading the focus will be on the need for equity in the allocation of ablution facilities.

\section{The measurement of gender equity}

In the introduction to this article, two methods of describing the level of gender discrimination were mentioned, namely economic measures and measurement by means of self-report surveys. These will be discussed in more detail in this section.

Research on gender and workplace stratification indicates that employment, wage and mobility gaps persist and that discrimination at the organisational and interactional levels also plays a role (Ortiz \& Roscigno, 2009). Current statistics may be interpreted as showing great gains in the number of women employed and the salaries they receive. In South Africa, for example, the percentage of women active in the labour force increased from 48.4 per cent in the 1980 s to 54.7 per cent in the early $1990 \mathrm{~s}$, reaching 61.7 per cent in late 1990 (International Labour Organization, 2002). Still, according to Van Klaveren, Tijdens, Hughie-Williams and Martin (2009), more men (7 558000$)$ then women (6 020000$)$ were employed in 2007 in South Africa. Thus, although women account for a larger proportion of working-age adults in South Africa, more men than women are employed. The International Labour Organization estimates the South African figures for 2008 at 7672000 for males and 6041000 for females (International Labour Organization, 2010). Observations on trends in the gender pay gap in South Africa vary. Hlekiso and Mahlo (2006) found that between 2001 and 2005 gender inequality persisted and the difference between wages for males and females grew from 31 per cent to 38 per cent. Based on Statistics South Africa's data on average wages, Burger and Yu (2006) observed that the gender pay gap increased over the 1995-2005 period, although the extent of the gap has narrowed since 2000. By contrast, calculations of real mean earnings based on data from the Department of Labour suggest that the gender pay-gap fell from 41 per cent in 1995 to 25 per cent in 2005 (Van Klaveren et al., 2009). South African research indicates that discrimination still plays a pivotal role in accounting for these wage differences (Goga, 2008; Muller, 2009).

Labour market data for South Africa give some indication of change over time, but their message is mixed and their interpretability is contestable. Barreto, Ryan and Schmitt (2009) report similar confusion when interpreting international and other data (eg Barrett, Alexander, Anesgart \& Doverspike, 1986; Gollob, 1984), indicating that a simple comparison between salaries or strata differences may not reveal actual gender discrimination.

Amaram (2010) states that that an undoubted gap in wages (and employment opportunities) for men and women continues today in most countries. However, Amaram (2010) also argues that part of the wage gap can be explained by the choices we make, rather than just by gender bias. He argues that bias in favour of men is not the only reason why women are paid less than men, suggesting that factors like education and fields of study, career choice, work patterns, marital and family status, as well as union affiliation, all contribute to the gap between men's and women's wages. Labour market data also reflect only one set of socio-economic differences between men and women. For 
example, Ortiz and Roscigno (2009) state that, despite continued political lobbying and legislative reform, the extent of women's advancement in society is generally unclear (Ortiz \& Roscigno, 2009). Research indicates that a simple comparison between salaries or strata differences may not reveal a comprehensive picture of gender discrimination (Barrett et al., 1986), which necessitates an alternative measure of progress.

Using the gap in men's and women's economic outcomes to quantify gender discrimination is a crude measure, as it relates to only one dimension of what discrimination may imply. Furthermore, omitted variables, unobserved heterogeneity, and measurement error can all confound statistical estimates of labour market discrimination. These econometric problems may have led to an increased interest in using alternative strategies, including surveys, to measure perceptions of gender discrimination (Antecol, Barcus \& CobbClark, 2009). Several measures of perceived discrimination have been developed and used in research. Examples of these are the Experiences of Discrimination (EOD) (Krieger, Smith, Naishadham, Hartman \& Barbeau, 2005), the Schedule of Sexist Events (SSE) (Klonoff \& Landrine, 1995) and the Quick Discrimination Index (QDI) (Ponterotto et al., 1995). In the EOD (Krieger et al., 2005) participants are asked a general question about experiences of discrimination, after which the focus moves to the types of discrimination (sex, country of birth, social class, sexual orientation, religion) suffered by participants, and where they occurred (at work, getting a job, discrimination at home by his or her partner, discrimination at home by others, when receiving medical care or being on the street or in a public setting). The SSE scale (Klonoff \& Landrine, 1995) consists of 13 items in which participants report on how often they have experienced gender discrimination during their lives in various settings. It includes questions such as "As a woman, how often have you been denied a raise, promotion, a job, or something at work that you deserved?" and "As a woman, how often have you been treated unfairly by your family?" The 30 items of the QDI focus on discrimination against groups such as women and racial minorities and on social issues, for example, affirmative action and bilingual education. The following is an example of an item from the QDI: "I think there is as much female physical violence toward men as there is male physical violence toward women" (Ponterotto, Potere \& Johansen, 2002).

As mentioned earlier, surveys are by their very nature often flawed (Shaughnessy et al., 2009), particularly surveys that assess aspects of out-groups (cf. Iyer \& Ryan, 2009; Navarrete et al., 2010; Sipe et al., 2009). For example, when assessing out-groups, there is a tendency to allocate more negative scores to the out-group, in contrast to how we judge our own in-groups, particularly when it comes to negative characteristics, such as unfair discrimination (Steyn, Nel \& Meiring, 2011).

\section{What constitutes an effective measure?}

The focus of the discussion on what makes an effective measure is limited and no specific attempt is made to present a comprehensive discussion in this article. However, the intention is to address the most important points. The basic requirement for any measure is that it should be reliable and valid (Rosnow \& Rosenthal, 2008; Shaughnessy et al., 2009; Terre Blanche, Durrheim \& Painter, 2006). Reliability refers, inter alia, to the stability or consistency of the measure. This is the terminal aspect of the measure and is traditionally reported as the correlation between the scores collected at Time 1 and Time 2 (Rosnow \& Rosenthal, 2008; Shaughnessy et al., 2009; Terre Blanche et al., 2006). When it comes to this study, would the data collected during 2010 correspond with the data that could be collected in 2012 ? Reliability also refers to the level of consensus between raters on a specific dimension (Rosnow \& Rosenthal, 2008). The higher the level of agreement, the higher the reliability is assumed to be. As far as this study is concerned, it would suggest that, if another researcher visited the same venues, s/he would find the same results.

Validity has external and internal dimensions. The external dimension refers to the extent to which the results of the measure can be used beyond the sample within which the data were collected when the measure was developed and norms were calculated (Rosnow \& Rosenthal, 
2008). In this study, it could be asked whether the results were applicable to other cities, other airports and other shopping centres. Internal validity has many dimensions, including face, content, construct and criteria validity. Face validity refers to the intuitive appeal of the instrument. A measure has high face validity when it is evident to the user that it assesses the construct it professes to measure (Rosnow \& Rosenthal, 2008). As far as this study is concerned, the question relates to whether other scholars would be convinced that the allocation of ablution facilities has any bearing on gender discrimination. Content validity, often used within the educational domain, has to do with how comprehensively the measure covers a particular domain (Rosnow \& Rosenthal, 2008). A test of mathematics that covers only algebra would, for example, not have high content validity because it did not also cover trigonometry and other domains. In this case the question would be whether the allocation of toilet facilities comprehensively describes the phenomenon of gender discrimination. Construct validity refers to the extent to which an instrument measures what it intends to measure (Rosnow \& Rosenthal, 2008; Shaughnessy et al., 2009; Terre Blanche et al., 2006). For example, does a test measure mathematical knowledge or just a student's knowledge of a particular lecture? In this case, does the unequal distribution of ablution facilities equate to gender discrimination? Lastly, criterion validity refers to the level to which the results on a certain measure correlate with an outcome. Will fewer toilets have an effect on women's legal rights, or their psychological, even physical health? This type of criterion validity is called concurrent validity when it refers to a present state of being, and predictive validity if it refers to a future state (Rosnow \& Rosenthal, 2008; Shaughnessy et al., 2009; Terre Blanche et al., 2006).

\section{Gender equity and the allocation of ablution facilities}

One argument for the allocation of ablution facilities would be to consider the number of each gender grouping in the population. The United Nations Statistics Division estimates that in 2010 there were approxi- mately 25590000 women in South Africa as opposed to 24903000 men (United Nations Statistics Division, 2010). As women account for 50.7 per cent of the South African population, it could be argued that women should have access to more ablution facilities than men have. The difference is, however, very small on a practical level and it could be argued that equal numbers of facilities should be allocated.

It could further be argued that the number of facilities provided at venues should depend on the gender grouping that visits that particular location most frequently. Historical beliefs or assumptions may dictate that men visit airports and train stations in greater numbers and that women visit shopping centres more frequently. This is not necessarily true, as is demonstrated in the case of the airport study done by Van Herck et al. (2004). The authors found in a convenient sample $(\mathrm{N}=5$ 465) drawn from several European airports that 49.6 per cent of travellers were women, and 50.4 per cent were men. Thanasupsin, Chaichana and Pliankarom (2010) also found small gender differences in the number of users of air services, where 50.6 per cent of users were women, and 49.4 per cent were men $(\mathrm{N}=2000)$. The assumption that significant differences exist in the gender groups that visit airports is thus not supported and these differences seem small on a practical level.

Following the same argument, the picture regarding shopping centres seems to support gender-based assumptions. In a study done by the European Food and Information Council (2008) in the United Kingdom, France, Germany, Sweden, Poland and Hungary, it was found that more women than men frequented shopping centres. This was true in all six countries surveyed. This is also the case with one of South Africa's leading retail stores, Woolworths, where between 75 per cent and 80 per cent of the 1 million people that pass through the retail chain's doors each month are female (Gebhardt, 2004). This may suggest that more facilities should be provided for women in and around these (shopping) facilities.

Research indicates that women spend more time in ablution facilities than men do. In a study conducted by Baillie, Fraser and Brown 
(2009), it was found that women $(\mathrm{M}=178.9$ sec., $\mathrm{SD}=96.6)$ spend significantly more time in the restroom than men do $(\mathrm{M}=118.4 \mathrm{sec}$., $\mathrm{SD}=102.6 ; \mathrm{t}(118)=-3.33, \mathrm{p}=.001 ; \mathrm{d}=.34)$. It was also found that woman engage in more activities, and for longer periods, when using ablution facilities. It was found that on average women wash their hands more often than men do when using these facilities (Edwards et al., 2002; Johnson, Sholcosky, Gabello, Ragni \& Ogonosky, 2003). Women also tend to use soap and dry their hands more frequently than men do (Garbutt, Simmons, Patrick \& Miller, 2007). Furthermore, women spend more time, almost twice that spent by men, looking at advertisements in toilets (BiziBox Media, 2010). This suggests that women's ablution facilities may be more congested than those of their male counterparts, which again suggests that more facilities should be made available to female users.

The last argument presented on the allocation of ablution facilities is a legislative or political argument. The Constitution of the Republic of South Africa of 1996, the South African Basic Conditions of Employment Act of 1997 and the Employment Equity Act of 1998 are often interpreted to suggest that resources should be distributed equally between the gender groups. The Nelson Mandela Metropolitan Municipality (Gysman, 2004), for example, strives to achieve a 50/50 representation of the gender groups in all its committees. Also, many others argue that the workforce does not represent the demographics of the country (cf Bowmaker-Falconer, Horwitz, Jain \& Taggar, 2003; Ramutloa, 2009), suggesting an underrepresentation of females. In line with the spirit of these statements it is argued that ablution facilities should be provided in line with the national demographics, implying that 50 per cent should be allocated to men and 50 per cent to women.

Given the argument presented here it should be expected that women have access to at least half the total number of ablution facilities provided in public spaces, especially in South Africa, given the political and legal climate that propagates equality at all levels of society. If not, this will equate to gender-based discrimination.

\section{Research design and procedures}

In collecting primary data on ablution facilities in South Africa, a cross-sectional research design was used. This design is suitable for describing the population as well as the calculation of correlations between measured constructs (Shaughnessy et al., 2009). The design suits this study well, as this research is primarily descriptive in nature.

\section{Sample and data collection process and methods}

The data were collected during the first six months of 2010. The target was ablution facilities provided to the public in major South African cities. Four major cities were visited to collect the data: Cape Town, Johannesburg, Durban and Pretoria. The first three cities were selected because they are, in terms of population, the largest cities in South Africa. Cape Town has approximately 3.7 million inhabitants, Johannesburg 8.8 million and Durban 3.2 million. Pretoria was included because it is considered to be the capital city of South Africa. In each city, four sites were visited: two well-known shopping centres, the largest airport and a train station. Only major shopping centres with at least four ablution facilities for each gender group were included. The aim was to collect data from four different ablution facilities (per gender) at each of the sites

The total number of facilities targeted amounted to 128 .

The unit of analysis was comprised of two components. The first component was urinals. Urinals are found in facilities designed for men only and are designed for urinating only. The second component was toilets. Toilets are designed for urinating and defecating. Toilets are found in facilities designated for men and women. All ablution facilities designed for use by Easterners and Middle Easterners were counted as toilets, and not as urinals, irrespective of whether they were located in male or female areas. For the purpose of this paper a toilet (even those designed for children, people in wheelchairs, and those designed for use by people from Eastern or Middle Eastern descent) or a urinal constitutes 
a unit, in other words a place where a person can urinate. Although it may be argued that urinals are not perfect substitutes for toilets, both represent a place to urinate, and will be seen as equivalent for the purpose of the data analysis.

Table 1

Sites visited for data collection

\begin{tabular}{|l|c|c|c|c|c|c|c|c|c|}
\hline & \multicolumn{2}{|c}{ Airport* $^{*}$} & \multicolumn{2}{c|}{ Train station } & \multicolumn{2}{c|}{ Shopping centre 1 } & \multicolumn{2}{c|}{ Shopping centre 2 } \\
\cline { 2 - 11 } & Male & Female & Male & Female & Male & Female & Male & Female \\
\hline Cape Town & 4 & 4 & 4 & 4 & 4 & 4 & 4 & 4 \\
\hline Johannesburg & 4 & 4 & 4 & 4 & 4 & 4 & 4 & 4 \\
\hline Durban & 4 & 4 & 4 & 4 & 4 & 4 & 4 & 4 \\
\hline Pretoria & 4 & 4 & 4 & 4 & 4 & 4 & 4 & 4 \\
\hline
\end{tabular}

*The newly renovated airports were visited.

At all the South African sites visited, the largest number of the ablution facilities was assigned to either men or women. Only a few were gender-nonspecific, namely those that were designed for families and others designed for people in wheelchairs. In categorising units available for men or women, the following strategy was followed: all units that were situated behind a sign indicating a particular gender were categorised as designated for that particular gender; all facilities indicating use by people in wheelchairs or family-friendly rooms, not situated in an area designated to a specific gender, were ignored in this survey, as both genders would have equal access to these units.

\section{Data analysis}

The aim was to assess whether differences existed in the number of facilities allocated to each gender group. This was done for the country as a whole as well as per city. In both cases t-tests were used. The Statistical Package for Social Scientists (SPSS Statistics 17) software was used to calculate the values. In all cases the effect size (eta square) of the differences was calculated manually using the formula $\mathrm{t}^{2} / \mathrm{t}^{2}+\left(\mathrm{N}_{1}+\mathrm{N}_{2}-2\right)$. Eta squared values of .01 were interpreted as a small effect, values of .06 as moderate and values of .14 and more as large (Cohen, 1988).

\section{5}

\section{Findings}

The findings fall into two parts, namely a discussion on the success of gathering data and the statistical analysis (including the descriptive statistics).

\section{Success of gathering data}

As indicated in Table 1 the intention was to visit four facilities for each gender group at 16 locations. This objective was achieved. The following locations were visited. In Cape Town, the Victoria and Alfred Waterfront and Canal Walk shopping centres were visited. Cape Town International Airport and the Cape Town Train Station were also visited. In Johannesburg, the focus fell on the Sandton City Centre and the Rosebank Mall, the Oliver R. Tambo International Airport and the Park Train Station. In Pretoria, the Menlyn Centre and Brooklyn Mall, the Lanseria International Airport and Pretoria Station were visited. In Durban, the Pavilion and Gateway shopping centres, the King Shaka International Airport and Durban Station formed part of the study. As planned, four facilities per gender were visited at each location $(\mathrm{N}=128)$.

\section{Statistical analyses}

The empirical results are provided under two headings, nationwide statistics and statistics per city. Descriptive statistics are provided in the text under both headings.

\section{Nationwide statistics}

The number of units in South Africa available to males at the 64 sites inspected was 642 and the number of units available to women, at the 64 sites visited, was 444 . The mean number of units available per site was 10.03 (standard deviation $=5.50$ ) for men and 6.94 (standard deviation $=3.35$ ) for women. There was a significant difference in the number of units available for men as opposed to women, with $\mathrm{t}(104.15)=3.84, \mathrm{p}<.000$ (equal variance not 
assumed). The magnitude of the difference in means (mean difference $=3.09$, 95 per cent CI : -4.68 to -1.49 ) was moderate to large (eta squared $=.10$ ). These results are presented in the last row of Table 2.

\section{City statistics}

In each city, 16 ablution facilities for males and 16 for females were visited. These results are reflected in Table 2 . In the last column of Table 2, it can be seen that, in most cases, the difference in allocation was practically meaningful.

To explain Table 2 better, the results for Cape Town are presented as an example. The number of units available to males in Cape Town was 163 and the number of units available to women was 104 . The details of the data collected for Cape Town are reflected in Table 3.

Table 2

Difference in the number of units allocated to men and women

\begin{tabular}{|c|c|c|c|c|c|c|c|}
\hline City & $\mathbf{N}$ & Male & Female & t-test & M Diff & $95 \% \mathrm{Cl}$ & $\mathrm{Eta}^{2}$ \\
\hline Cape Town & 32 & $\begin{array}{l}M=10.19 \\
S D=6.02\end{array}$ & $\begin{array}{l}M=6.50 \\
S D=1.86\end{array}$ & $\begin{array}{l}t(30)=2.33 \\
p=.026\end{array}$ & 3.68 & .46 to 6.91 & .13 \\
\hline Johannesburg & 32 & $\begin{array}{l}M=12.94 \\
S D=6.21\end{array}$ & $\begin{array}{l}M=9.13 \\
S D=3.67\end{array}$ & $\begin{array}{l}t(30)=2.11 \\
p=.043\end{array}$ & 3.81 & .12 to 7.49 & .12 \\
\hline Durban & 32 & $\begin{array}{l}M=8.82 \\
S D=3.79\end{array}$ & $\begin{array}{l}M=7.00 \\
S D=3.68\end{array}$ & $\begin{array}{l}t(30)=1.37 \\
p=.181\end{array}$ & 3.81 & -.89 to 4.51 & .05 \\
\hline Pretoria & 32 & $\begin{array}{l}M=8.19 \\
S D=4.83\end{array}$ & $\begin{array}{l}M=5.13 \\
S D=2.80\end{array}$ & $\begin{array}{l}t(24)^{n}=2.19 \\
p=.036\end{array}$ & 3.06 & .180 to 5.94 & .13 \\
\hline All & 128 & $\begin{array}{l}M=10.03 \\
S D=5.50\end{array}$ & $\begin{array}{l}M=6.94 \\
S D=3.35\end{array}$ & $\begin{array}{l}t(104)^{n}=3.84 \\
p<.000\end{array}$ & 3.09 & -1.49 to -4.68 & .10 \\
\hline
\end{tabular}

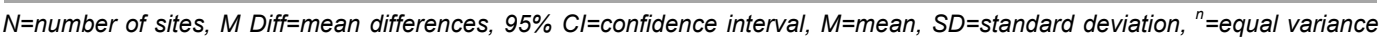
not assumed.

Table 3

Ablution facilities in Cape Town

\begin{tabular}{|c|c|c|c|c|}
\hline & Site & Male & Female & Percentage \\
\hline \multirow[t]{4}{*}{ Cape Town International Airport } & 1 & $\mathrm{~T} 3+\mathrm{U} 3=\mathrm{P} 6$ & $\mathrm{~T} 3=\mathrm{P} 3$ & $3 / 6=50$ \\
\hline & 2 & $\mathrm{~T} 5+\mathrm{U} 5=\mathrm{P} 10$ & $\mathrm{~T} 6=\mathrm{P} 6$ & $6 / 8=75$ \\
\hline & 3 & $\mathrm{~T} 4+\mathrm{U} 3+\mathrm{W} 1=\mathrm{P} 8$ & $\mathrm{~T} 4+\mathrm{C} 1=\mathrm{P} 5$ & $5 / 8=63$ \\
\hline & 4 & $\mathrm{~T} 3+\mathrm{U} 3+\mathrm{W} 1=\mathrm{P} 7$ & $\mathrm{~T} 4+\mathrm{C} 1=\mathrm{P} 5$ & $5 / 7=71$ \\
\hline \multicolumn{2}{|l|}{ Total } & $P=31$ & $P=19$ & $19 / 31=61$ \\
\hline \multirow[t]{4}{*}{ Cape Town Train Station } & 1 & $\mathrm{~T} 12+\mathrm{U} 18+\mathrm{M} 1=\mathrm{P} 31$ & $\mathrm{~T} 8=\mathrm{P} 8$ & $8 / 31=26$ \\
\hline & 2 & $\mathrm{~T} 2+\mathrm{U} 3+\mathrm{W} 1+\mathrm{M} 1=\mathrm{P} 7$ & $\mathrm{~T} 5+\mathrm{W} 1+\mathrm{M} 1=\mathrm{P} 7$ & $7 / 7=100$ \\
\hline & 3 & $\mathrm{~T} 2+\mathrm{U} 3+\mathrm{W} 1+\mathrm{M} 1=\mathrm{P} 7$ & $\mathrm{~T} 5+\mathrm{W} 1+\mathrm{M} 1=\mathrm{P} 7$ & $7 / 7=100$ \\
\hline & 4 & $\mathrm{~T} 2+\mathrm{U} 3+\mathrm{W} 1+\mathrm{M} 1=\mathrm{P} 7$ & $\mathrm{~T} 5+\mathrm{W} 1+\mathrm{M} 1=\mathrm{P} 7$ & $7 / 7=100$ \\
\hline \multicolumn{2}{|l|}{ Total } & $P=52$ & $P=29$ & $29 / 52=56$ \\
\hline \multirow[t]{4}{*}{ Victoria \& Alfred Waterfront Centre } & 1 & $\mathrm{~T} 2+\mathrm{U} 7+\mathrm{W} 1=\mathrm{P} 10$ & $\mathrm{~T} 9+\mathrm{W} 1=\mathrm{P} 10$ & $10 / 10=100$ \\
\hline & 2 & $\mathrm{~T} 6+\mathrm{U} 5=\mathrm{P} 11$ & $\mathrm{~T} 8=\mathrm{P} 8$ & $8 / 11=73$ \\
\hline & 3 & $\mathrm{~T} 5+\mathrm{U} 8+\mathrm{M} 1=\mathrm{P} 14$ & $\mathrm{~T} 6+\mathrm{M} 2=\mathrm{P} 8$ & $8 / 14=57$ \\
\hline & 4 & $\mathrm{~T} 3+\mathrm{U} 8+\mathrm{W} 1+\mathrm{M} 1=\mathrm{P} 13$ & $\mathrm{~T} 6+\mathrm{W} 1+\mathrm{M} 1=\mathrm{P} 8$ & $8 / 13=63$ \\
\hline \multicolumn{2}{|l|}{ Total } & $P=48$ & $P=34$ & $34 / 48=71$ \\
\hline \multirow[t]{4}{*}{ Canal Walk Shopping Centre } & 1 & $\mathrm{~T} 3+\mathrm{U} 3=\mathrm{P} 6$ & $\mathrm{~T} 3=\mathrm{P} 3$ & $3 / 6=50$ \\
\hline & 2 & $\mathrm{~T} 4+\mathrm{U} 4=\mathrm{P} 8$ & $\mathrm{~T} 6=\mathrm{P} 6$ & $6 / 9=67$ \\
\hline & 3 & $\mathrm{~T} 2+\mathrm{U} 6+\mathrm{M} 1=\mathrm{P} 9$ & $\mathrm{~T} 6=\mathrm{P} 6$ & $6 / 9=67$ \\
\hline & 4 & $\mathrm{~T} 2+\mathrm{U} 5+\mathrm{M} 1+\mathrm{C} 1=\mathrm{P} 9$ & $\mathrm{~T} 6+\mathrm{C} 1=\mathrm{P} 7$ & $7 / 9=78$ \\
\hline \multicolumn{2}{|l|}{ Total } & $P=32$ & $P=22$ & $22 / 32=68$ \\
\hline TOTAL & 16 & $P=163$ & $P=104$ & $104 / 163=64$ \\
\hline
\end{tabular}

$T=$ toilet, $U=$ urinal, $W=$ wheelchair, $M=$ facility for Easterners/Middle Easterners, $C=$ family-friendly facilities, $P=$ units 
From Table 3 it can be read that, in the first facility visited at the Cape Town International Airport, there were three toilets and three urinals provided for men (accounting for six units) and three toilets for women (three units). The total number of units provided for males at Cape Town International Airport was 31 as opposed to the 19 provided for females. At this facility women had access to 61 per cent fewer units than men. From Table 2 it is clear that the picture is very similar at all the Cape Town facilities, where, in total, 163 facilities were found to be allocated to men compared with the 104 provided for women. In Cape Town women had, on average, access to 64 per cent of the facilities to which men had access. The mean per site was 10.19 (standard deviation = 6.02) for men and 6.50 (standard deviation = 1.86) for women (Table 2). An independent sample t-test was conducted to compare the number of urinary facilities available to men and women. The results are listed in Table 2 . There was a significant difference in the number of units available to men in comparison with those available to women, with $\mathrm{t}(30)=2.33, \mathrm{p}=.026$ (equal variance assumed). The magnitude of the difference in means (mean difference $=3.68,95$ per cent $\mathrm{CI}$ : .46 to 6.91 ) was moderate to large (eta squared $=.13$ ).

The number of units available to men in Johannesburg was 207 and the number of units available to women was 146 . There was a significant difference in the number of units available for males as opposed to females, and the magnitude of the difference was moderate to large (see Table 2). The picture is very much the same for Pretoria. The number of units available to males in Pretoria was 131 and the number of units available to females was 82 . There was a significant difference in the number of units available for men and for women, with the magnitude of the difference in means being moderate to large. For Durban the picture is somewhat different. Although the number of units available in Durban to men (141) was more than the number of units available to women (112), there was no significant difference $(p=.181)$ in the number of units available (see Table 2). The effect size (.05) was small to moderate.

\section{6}

\section{Discussion}

In Section 3 of this article an indication of the requirements for an effective measure was provided. Let us firstly consider reliability. Counting units seems to be a reliable measure of discrimination. When it comes to test-retest reliability the likelihood that the count taken during this survey (2010) will differ from counts taken in the near future (2012) is small, as constructing new ablution facilities or modifying them generally takes a long time. Also, many of these facilities were constructed as recently as 2010. Reliability also refers to the level of consensus between raters. When using this measure and the guidelines set out in counting units as described in Section 4, interrater reliability should be very high. Thus, if other researchers were to visit the same venues and apply the same methodology, they would find similar results.

In assessing the validity of the measure, there have to be some subjective judgments. When considering external validity and asking whether the results could be applied to other cities (other airports, as well as other shopping centres) and other countries, the answer may be affirmative. This is because population distributions are generally 50/50 per gender, and unitary segregation happens in many countries, so using the measure in other contexts may be useful. When unequal numbers of facilities are provided in a 50/50 male/female setting, this should equate with discrimination, irrespective of the setting.

Four types of internal validity were discussed in Section 3. Considering the proportion of facilities available to each gender grouping, where the gender composition of the population in that environment is available, has an intuitive appeal as a measure of equitable distribution of facilities and gender discrimination. This suggests face validity. Counting the number of facilities available for urination hardly provides a comprehensive measure of the state of the gender discrimination domain, but it does provide a very reliable and appealing measure. As stated earlier, the intention of introducing the measure was not to provide a comprehensive measure, but rather to supply additional and tangible information. 
The fact that the disproportionate allocation of toilet facilities represents a part of what gender discrimination is about suggests some content validity (the content being the gender discrimination domain). If construct validity refers to the extent to which an instrument measures what it intends to measure, this measure may do precisely that, as it clearly differentiates between males and females and the level of access they have to basic services. It thus measures gender distribution of facilities and gender discrimination. The last type of validity, criterion validity, refers to the level at which the results using a certain measure correlate with an outcome. This is the case with this measure. When limited facilities are available to a specific group and if that group endures discomfort and even embarrassment due to the differentiation, this will constitute tangible (as compared to perceived) discrimination. The queues we often observe in front of ablution facilities designated to women (in contrast with facilities designed for men) are concrete evidence of the poor and discriminatory allocation of these facilities. In summary, it seems that the counting of opportunities for urination can be a very valid measure of gender-based discrimination, despite the measure not generally being labelled as such.

Merely stating that the allocation of toilets in public spaces constitutes an additional measure of discrimination does not fully tackle the gravity of the level of discrimination detected when using this measure. With regard to the data presented, South African women seem to be at a real disadvantage compared with men. For every 100 units available to men in urban areas, women have access to only 69. This just does not make any sense in a country where 50 per cent of the population is female and where all are regarded as equal before the law. This situation is even worse when we consider that women use ablution facilities for more than one reason, and that there are culture-specific taboos and practices which imply that women often need to spend more time in ablution facilities. Women's needs should thus be considered when these facilities are being designed. This places a responsibility on men, as most toilets are imagined (designed), provided and managed by males (Greed, 2009), who are quite often ignorant about the real requirements of women (Penner, 2009).

This is, however, not only a matter of comfort or functional design, as the inappropriate allocation of ablution facilities also infringes on women's legal rights, their psychological wellbeing, and their physical health. The problem may require lobbying at different levels, as this proved successful in lessening discrimination relating to the availability of restrooms in the United States of America (Anthony \& Dufresne, 2009). A first simple step may be, when visiting the theatre next time, to ask the manager why women should stand in a queue when visiting the ablution facility during the interval (a planned event), whilst men do not experience the same inconvenience.

\section{References}

AMARAM, D.I. 2010. The gender pay gap: review and update. China-USA Business Review, 9(6):51-58. ANTECOL, H., BARCUS, V.E. \& COBB-CLARK, D. 2009. Gender-biased behavior at work: exploring the relationship between sexual harassment and sex discrimination. Journal of Economic Psychology, 30(5): 782-792.

ANTHONY, K.H. \& DUFRESNE, M. 2009. Potty privilege in perspective: gender and family issues in toilet design. In O Gershenson \& B Penner (eds.) Ladies and gents: public toilets and gender (pp. 48-61). Philadelphia, PA: Temple University Press.

BAILLIE, M.A., FRASER, S. \& BROWN, M.J. 2009. Do women spend more time in the restroom than men? Psychological Report, 105(3):789-790.

BARRETO, M., RYAN, M.K. \& SCHMITT, M.T. 2009. The glass ceiling in the 21st century: understanding barriers to gender equality. Psychology of women book series. Washington, DC: American Psychological Association. 
BARRETT, G.V., ALEXANDER, R.A., ANESGART, M.N. \& DOVERSPIKE, D. 1986. Frequently encountered problems in the application of regression analysis to the investigation of sex discrimination in salaries. Public Personnel Management, 15(2):143-157.

BIBLE, D. \& HILL, K. 2007. Discrimination: women in business. Journal of Organizational Culture, Communication and Conflict, 11(1):65-76.

BIZIBOX MEDIA. 2010. Toilet advertizing: targeting your audience ... Available at: http://www.rightresults4u.com/toiletadvertising.htm [accessed 2010-09-13].

BOWMAKER-FALCONER, A., HORWITZ, F.M., JAIN, H. \& TAGGAR, S. 2003. Employment equality programmes in South Africa: current trends. Industrial Relations Journal, 29(3):222-233.

BURGER, R. \& YU, D. 2006. Wage trends in post-apartheid South Africa: constructing an earnings series from household survey data. South African Reserve Bank: Labour Market Frontiers, 8:1-8.

CARR, P.L., ASH, A.S., FRIEDMAN, R.H., SZALACHA, L., BARNETT, R.C., PALEPU, A et al., 2000. Faculty perceptions of gender discrimination and sexual harassment in academic medicine. Annals of Internal Medicine, 132:889-896.

CASCIO, W.F. 2010. Managing human resources: productivity, quality of work life, profits (8th ed.) Boston: MA: McGraw-Hill Irwin.

COHEN, J.W. 1988. Statistical power analysis for behavioral sciences (2nd ed.) Hillsdale, NJ: Lawrence Erlbaum Associates.

EDWARDS, D., MONK-TURNER, E., POORMAN, S., RUSHING, M., WARREN, S. \& WILLIE, J. 2002. Predictors of hand-washing behavior. Social Behavior and Personality: an International Journal, 30(8): 751-756.

EUROPEAN FOOD AND INFORMATION COUNCIL. 2008. Pan-European consumer research on European consumers' nutrition knowledge and in-store behaviour, understanding and use of nutrition information on food labels. Available at: http://www.eufic.org/upl/1/default/doc/Research\%20MethodologyEN-09.pdf [accessed 2010-09-13].

GARBUTT, C., SIMMONS, G., PATRICK, D. \& MILLER, T. 2007. The public hand hygiene practices of New Zealanders: a national survey. Journal of the New Zealand Medical Association, 120(1265):27-33. GEBHARDT, M. 2004. Woolworths keeps a sharp eye on what a woman wants. July 5, 2004, Business Report.

GOGA, S. 2008. Understanding the gender earnings gap in the post-apartheid South African labour market. Thesis (M.Com.), University of KwaZulu-Natal, Durban. Available at: http://researchspace.ukzn.ac.za/ xmlui/handle/10413/ 1201 [accessed 2011-08-26].

GERSHENSON, O. \& PENNER, B. 2009. Private life of public conveniences. In O Gershenson \& B Penner (eds.) Ladies and gents: public toilets and gender (pp. 1-32). Philadelphia, PA: Temple University Press.

GOLLOB, H.F. 1984. Detecting sex bias in salaries. American Psychologist, 39(4):448-451.

GREED, C. 2009. The role of the public toilet in civic life. In O Gershenson \& B Penner (eds.) Ladies and gents: public toilets and gender (pp. 36-47). Philadelphia, PA: Temple University Press.

GYSMAN, N. 2004. Nelson Mandela Metropolitan Municipality: Gender and woman empowerment policy. Available at: http://www.nelsonmandelabay.gov.za/Documents.aspx?objID=85.pdf [accessed 2010-09-25.

HLEKISO, T. \& MAHLO, N. 2006. Wage trends and inequality in South Africa: a comparative analysis. South African Reserve Bank: Labour Market Frontiers, 8:9-16.

INTERNATIONAL LABOUR ORGANIZATION. 2002. Key indicators of the labour market 2001-2002. Geneva: International Labour Office.

INTERNATIONAL LABOUR ORGANIZATION. 2010. Statistics per country. Available at: http://laborsta.ilo.org/STP/guest [accessed 2010-12-22].

IYER, A. \& RYAN, M.K. 2009. Why do men and women challenge gender discrimination in the workplace? The role of group status and in-group identification in predicting pathways to collective action. Journal of Social Issues, 65(4):791-814.

JOHNSON, H.D., SHOLCOSKY, D., GABELLO, K., RAGNI, R. \& OGONOSKY, N. 2003. Sex differences in public restroom handwashing behavior associated with visual behavior prompts. Perceptual and Motor Skills, 3(1):805-810. 
KLONOFF, E. \& LANDRINE, H. 1995. The schedule of sexist events: a measure of lifetime and recent sexist discrimination in women's lives. Psychology of Women Quarterly, 9(4):439-472.

KRIEGER, N., SMITH, K., NAISHADHAM, D., HARTMAN, C. \& BARBEAU, E.M. 2005. Experiences of discrimination: validity and reliability of a self-report measure for population health research on racism and health. Social Science and Medicine, 61(7):1576-1596.

LEOPOLD, J. \& HARRIS, L. 2009. The strategic management of human resources (2nd ed.) Essex: Pearson Education.

MOORE, A. 2009. Colonial visions of third world toilets: a nineteenth-century discourse that haunts contemporary tourism. In O Gershenson \& B Penner (eds.) Ladies and gents: public toilets and gender (pp. 105-125). Philadelphia, PA: Temple University Press.

MULLER, C. 2009. Trends in the gender wage gap and gender discrimination among part-time and fulltime workers in post-apartheid South Africa. Working Paper 124, University of KwaZulu-Natal, Durban. Available at: http://www.econrsa.org/papers/w_papers/wp124.pdf [accessed 2011-08-26].

NAVARRETE, C.D., MCDONALD, M.M., MOLINA, L.E. \& SIDANIUS, J. 2010. Prejudice at the nexus of race and gender: an outgroup male target hypothesis. Journal of Personality and Social Psychology, 98(6): 933-945.

ORTIZ, S.Y. \& ROSCIGNO, V.J. 2009. Discrimination, women, and work: processes and variations by race and class. The Sociological Quarterly, 50(2):336-359.

PENNER, B. 2009. (Re)designing the unmentionable: female toilets in the twentieth century. In O Gershenson \& B Penner (eds.) Ladies and gents: Public toilets and gender (pp. 141-150). Philadelphia, PA: Temple University Press.

PONTEROTTO, J.G., BURKARD, A., RIEGER, B.P., GRIEGER, I., D'ONOFRIO, A., DUBUISSON, A., et al. 1995. Development and initial validation of the Quick Discrimination Index (QDI). Educational and Psychological Measurement, 55:1026-1031.

PONTEROTTO, J.G., POTERE, J.C. \& JOHANSEN, S.A. 2002. The Quick Discrimination Index: normative data and user guidelines for counseling researchers. Journal of Multicultural Counseling and Development, 30(3):192-207.

RAMUTLOA, E. 2009. Commission for Employment Equity Report 2007-2008. Available at: http://www.labour. gov.za/ documents/annual-reports/Commission\%20for\%20Employment\%20Equity\%20 Report/2007-2008/commission-for-employment-equity-report-2007-2008 [accessed 2010-09-13].

ROSNOW, R.L. \& ROSENTHAL, R. 2008. Beginning behavioral research: a conceptual primer (6th ed.) Upper Saddle Road, NJ: Pearson/Prentice-Hall.

SCHWEDER, A. 2009. Stalls between the walls: segregated sexed spaces. In O Gershenson \& B Penner (eds.) Ladies and gents: public toilets and gender (pp. 182-188). Philadelphia, PA: Temple University Press. SHAUGHNESSY, J.J., ZECHMEISTER, E.B. \& ZECHMEISTER, J.S. 2009. Research methods in psychology (8th ed.) New York, NY: McGraw-Hill.

SIPE, S, JOHNSON, C.D. \& FISHER, D.K. 2009. University students' perceptions of gender discrimination in the workplace: reality versus fiction. Journal of Education for Business, 84(6):339-349.

SOUTH AFRICA. 1998. Employment Equity Act 55 of 1998. Pretoria: Government Printer.

STEYN, R., NEL, J. \& MEIRING, D. 2011. Adaptation of the Modern Racism Scale for use in South Africa. A manuscript included in the proceedings of the 5th International Business Conference, Grand Mauritian Hotel, Turtle Bay, Balaclava, Mauritius, 26-30 September 2011.

TERRE BLANCHE, M., DURRHEIM, K. \& PAINTER, D. (eds.) 2006. Research in practice: applied methods for the social sciences (2nd ed.). Cape Town: UCT Press.

THANASUPSIN, K., CHAICHANA, S. \& PLIANKAROM, S. 2010. Factors influencing mode selections of low-cost carriers and a full-service airline in Thailand. Transportation Journal, 49:35-47.

VAN HERCK, K., CASTELLI, F., ZUCKERMAN, J., NOTHDURFT, H., VAN DAMME, P.,

DAHLGREN, A-L., et al., 2004. Knowledge, attitudes and practices in travel-related infectious diseases: the European airport survey. Journal of Travel Medicine, 11(1):3-8.

VAN KLAVEREN, M., TIJDENS, K., HUGHIE-WILLIAMS, M. \& MARTIN, N.R. 2009. An overview of women's work and employment in South Africa: Decisions for life MDG3 project country report no. 3. University of Amsterdam, Amsterdam: Amsterdam Institute for Advanced Labour Studies. 
UNITED NATIONS. 1948. Universal Declaration of Human Rights (General Assembly resolution 217 A III). Available at: http://daccess-dds-ny.un.org/doc/RESOLUTION/GEN/NR0/043/88/IMG/NR004388.pdf [accessed 2010-09-13].

UNITED NATIONS STATISTICS DIVISION. 2010. The world's women 2010: Trends and statistics. Available at: http://unstats.un.org/unsd/demographic/products/Worldswomen/WW_full\%20report_color.pdf [accessed 2012-04-03]. 